\title{
Development of Biorefineries in the Bioeconomy: A Fuzzy-Set Qualitative Comparative Analysis among European Countries
}

\author{
Zhengqiu Ding ${ }^{1,2, *}$ and Philipp Grundmann ${ }^{1,2} \mathbb{D}$ \\ 1 Technology Assessment and Substance Cycles, Leibniz Institute for Agricultural Engineering and \\ Bioeconomy (ATB), 14469 Potsdam, Germany; pgrundmann@atb-potsdam.de \\ 2 Department of Agricultural Economics, Humboldt-Universität zu Berlin, 10099 Berlin, Germany \\ * Correspondence: zding@atb-potsdam.de
}

check for

updates

Citation: Ding, Z.; Grundmann, P.

Development of Biorefineries in the Bioeconomy: A Fuzzy-Set Qualitative Comparative Analysis among European Countries. Sustainability 2022, 14, 90. https://doi.org/ $10.3390 /$ su14010090

Academic Editors: Silvio Matassa, Willy Verstraete and Idiano D'Adamo

Received: 18 November 2021 Accepted: 17 December 2021 Published: 22 December 2021

Publisher's Note: MDPI stays neutral with regard to jurisdictional claims in published maps and institutional affiliations.

Copyright: (c) 2021 by the authors. Licensee MDPI, Basel, Switzerland. This article is an open access article distributed under the terms and conditions of the Creative Commons Attribution (CC BY) license (https:// creativecommons.org/licenses/by/ $4.0 /)$.

\begin{abstract}
This study aims to identify the configurational conditions that characterize the establishment of biorefineries in 20 European countries. After determining the conditions which support a bioeconomy transition, secondary data from national sources are used to represent their existing conditions within respective countries. Then, a fuzzy-set qualitative comparative analysis is employed to compare and contrast the effect of varying combinations of the selected conditions on the development of biorefineries. The conditions chosen include coherent bioeconomy strategies, network intensity of regional bioclusters, intellectual capital, and natural resource availability. Our results reveal that the configuration of a coherent bioeconomy strategy, sizable public spending on $R \& D$, abundant biomass supply, and a high level of network intensity is sufficient to explain the pronounced biorefineries development among some European countries. We recommend that countries with fragmented approaches review and redesign the policy and regulatory framework to create a holistic and consistent bioeconomy strategy, taking into account the configurations of conditions as an important prerequisite. In particular, factors such as the lack of best practice examples, the low level of public spending on research and development, the economic capacities for a skilled workforce in addition to the sustainable supply of raw materials should be addressed as focal points.
\end{abstract}

Keywords: bioeconomy development; biorefineries; transition framework; configurations of conditions; fuzzy-set; qualitative comparative analysis

\section{Introduction}

Countries in Europe and around the world are seeking to develop their bioeconomies. Most of them are supporting the transition to a bioeconomy through comprehensive political means [1]. Staffas et al. [2] analyzed strategies and policies towards bioeconomy at the supra-national (e.g., EU and OECD) and national (e.g., Germany, Sweden, and Finland) levels. However, few studies compare countries in the different phases of their bioeconomy development: no bioeconomy strategies at all, strategies currently undergoing development, or countries with policy initiatives dedicated to the bioeconomy, but no strategy. For example, the Czech Republic has not developed a separate strategy for its bioeconomy, however, other policies support research and innovation in other bioeconomy related fields [3]. Moreover, Bosman and Rotmans [4] emphasized that a country's geographic location, natural resources, and economies will dictate their bioeconomy approach. Their analysis draws a distinction between Finish and Dutch bioeconomies. Forestry biomass is abundant in Finland, whereas it is limited in the Netherlands, and so the development of bio-based products alongside chemical processing technology help drive the Finish bioeconomy [4]. Bioeconomy transition is a complex endeavor that requires sustainable partnerships and goals across varying industries, feedstocks, and countries [5]. Another aspect of the dynamic system includes the link between natural resources and technology in addition to the influence of markets, people and policy [6]. Such relationships may not be symmetric, and similar developments can occur in different configurational conditions 
for bioeconomy development. Based upon Complexity Theory [7], different configurations of conditions may be sufficient to trigger a transition, and no single condition is expected to achieve the specific outcome.

One of the technical and organizational innovations in the transition to a bioeconomy is the emergence of biorefineries [8-10]. The biorefinery concept is built on complex arrangements of processes for converting different types of biomass by applying various types of conversion technologies, and generating bioenergy and a variety of bio-based products $[10,11]$. This study focuses on the case of biorefineries, since these are described as important innovations in the transition of bio-based industries towards a circular bioeconomy [12]. Further, in light of sustainability, biorefineries are able to deliver products that have less environmental impact compared with petroleum refineries. And in the biorefinery production system, the conversion of multiple biomasses could also ensure economic benefits [13]. However, the number of biorefinery facilities in European countries varies notably [14] (as shown in Appendix A Figure A1). Previous studies have empirically assessed factors that drive the diffusion and implementation of biorefineries, using approaches such as technology innovation systems (TIS) [10] and a multi-phase Delphi study $[15,16]$. Some of the associated conditions identified from these studies include political issues, resource availability, R\&D funding, business networks for collaboration, and knowledge as well as human capital [10,15-17]. However, most of the analyses focus on single countries and, so far, no study has conducted a cross-national analysis to characterize the configurational conditions contributing to the variation in biorefinery development across Europe. This study uses indicators based upon these conditions and then parameterizes the salient markers. These inputs are used to construct a prospective comparative analysis that quantifies the interrelationships by estimating the significance of these conditions on biorefinery development. Therefore, this article aims to distinguish the relevant conditions for biorefinery development by answering the following questions: what configurational conditions contribute to current biorefinery development in 20 European countries. The second line of investigation addresses the disparity in the number of biorefinery facilities throughout Europe. We investigate why some countries have a more dynamic development of biorefineries than others.

The benefits of shifting to a bioeconomy are widely recognized, however, there is a lack of empirical research identifying the specific context of the conditions that allow for a successful transition [18]. Insight about the contextual differences between countries will establish a practical framework for interpreting bioeconomy outcomes of various configurational patterns. More knowledge about the sufficient conditions that drive bioeconomy development will allow countries to prioritize the key fields of improvement, redirect their policies accordingly and take the appropriate considerations for their specific situation. Thus, this study contributes to existing knowledge examining whether a country's effort on developing strategies and policies that explicitly promote the bioeconomy makes a difference in terms of economic development. By differentiating these factors at the national, regional, and macro-regional level, offers insight into how the presence or absence of these conditions produces variation in biorefinery development throughout Europe.

\section{Theoretical Background on Conditions for Transition to a Bioeconomy}

A growing number of scholars are engaging in the development of conceptual and analytical frameworks for monitoring and assessing bioeconomy transitions $[1,19,20]$. The current transition frameworks include conditions and driving forces for bioeconomy transitions, such as strategy and policy on the demand side, and biomass and labor resource on the supply side. A reinforcing interaction between the driving forces, for example between population growth and technological innovation or social and political actions, is crucial for the process of transitioning to a bioeconomy [1]. 


\subsection{Bioeconomy Strategies and Initiatives across Different Levels}

Golden [21] studied national strategy in the context of economic development. $\mathrm{He}$ described that "a national strategy is the vision of the process through which national resources will be used to achieve national objectives. National strategies may be distinguished by the relative roles given to the private and public sectors, the emphasis given to different policy instruments and the importance assigned to various possible outcomes" [21]. Thus, national strategies reflect the policies on issues with the highest national interest and make coordination and assessments on the trade-offs within that strategic context possible. In this article, we covered the same rationale in the context of bioeconomy development. Goven and Pavone [22] advocate that the bioeconomy needs to be framed as a political project and not only or primarily as a techno-scientific or economic one. Countries with a national strategy for bioeconomy development address a broad spectrum of objectives and intentions in a more coordinated way, sometimes including the aspects of protecting biodiversity, food quality, and climate change mitigation [2]. In the German national bioeconomy strategy, the Federal Government lays down the guidelines and objectives for policy on bioeconomy and lists measures for implementation in the coming years [23]. Most countries and economies in Europe have adopted national bioeconomy strategies. It indicates the sector's relevance for different parts of society in addition to its potential economic contribution. In addition, bioeconomy transition is not only about constantly evolving and summarizing existing knowledge, but also the development of new strategies and innovative technological processes for the direction of transformation taking the global, regional and local specificities into consideration [24]. Therefore, the regional and macro-regional bioeconomy strategies will also play an important role in this transition process. With a regional strategy on the bioeconomy, the local government plays a facilitating role in advancing the regional bioeconomy development through creating opportunities for collaboration between industries, research institutes, and entrepreneurs, and through providing communication between other local stakeholders [25]. To align with the bioeconomy development and sustainable development goals, some countries in Europe have adopted the bioeconomy monitoring framework to ensure the sustainable development in bioeconomy sectors.

To develop a framework condition for bioeconomy transition also requires a steering process [26], for instance, the diffusion of bio-based knowledge and innovations, as well as build up partnership to enhance collaborations and co-investment in bioeconomy sectors. Under policy frameworks, clusters are expected to steer the transition to a bio-based economy by fostering innovation, knowledge transfer, and rural development [1]. Thus, clusters play a role in facilitating bioeconomy strategic development and allowing for alignment between their mandates and sectoral objectives with national bioeconomy strategy goals and objectives.

\subsection{Bioclusters Promoting Collaboration and Knowledge Transfer in Bioeconomy}

In a meta-analysis on the framework for bioclusters, the authors demonstrate that most biocluster cases in their analysis emphasize knowledge accumulation and learning for the connection with the outside world. Further, they conclude that the network intensity of clusters contributes positively to knowledge accumulation and learning [27]. One of the well-established definitions for a cluster comes from the book "Industrial Clusters in Biotechnology" [28]: "A cluster is a geographical concentration of actors in vertical and horizontal relationships, showing a clear tendency of cooperating and sharing their competencies, all involved in a localized infrastructure of support". Zechendorf [29] concludes that bioclusters are the clusters engaged in the field of biosciences, and they have contributed substantially to the development of the bioeconomy. Governmental strategies consider biocluster initiatives to be the drivers of regional economic development [29]. They also promote collaborations between research institutions, local bio-based industries, and entrepreneurs, as well as strengthening the regional employment [30]. Furthermore, bioclusters could perform the function of sharing, transferring and scaling-up knowledge generated within single companies to link with other partners inside and outside the 
clusters. In this way, innovation could be improved and used for the development of products, technologies, and services [29]. Bioclusters can promote the diffusion of expertise and knowledge among the members and support the commercialization of technologies and innovations from the research.

\subsection{Intellectual Capital for Bioeconomy Development}

Intellectual capital refers to the sum of the knowledge, information, technologies, skills, expertise, intellectual property, customer loyalty, and team management that contribute to organizational performance by creating values on products and services (Stewart, 1997, as cited in [31]). Kozak [32] points out that the concept of intellectual capital is still underdeveloped, and there is no uniform definition accepted for identifying its dimensions. According to a sustainable competitiveness report [33], intellectual capital is the capability to generate wealth and jobs through innovation and value added industries in the globalized markets. In this sustainable competiveness report the components for measuring the intellectual capital index include education, R\&D and new businesses. Recent years have seen the applications of intellectual capital on bioeconomy studies. For instance, Boljanovic et al. [34] analyzed the indicators of intellectual capital in the food industry of Serbia. Gărdan et al. [35] studied bioeconomy development by using intellectual capital for the creation of competitive advantages in the field of biotechnology SMEs. Furthermore, scholars have proposed the prerequisites for a sustainable bioeconomy transition, namely skilled labor by improved education and training, meanwhile enhancing research and innovation through the R\&D funding $[10,19,20]$. Zilberman et al. [36] posit that the development of bioeconomy desires new major modifications on education, training, and research. Urmetzer and Pyka [37] demonstrate that the transition to a knowledge-based bioeconomy entails new skills acquired by the graduates of higher education to be applied in the bioeconomy sectors. These factors indicate the importance of intellectual capital for bioeconomy development. Anghel et al. [38] conclude that intellectual capital plays a role in promoting bioeconomy transition, particularly for biomass transformation.

In this article, we investigate the dimensions of intellectual capital related to human capital measured by their educational attainment level and R\&D expenses.

1. Human capital: To advance the bioeconomy transition, demographic factors like the skilled workforce play an essential role. Human capacity is a fundamental factor for bioeconomy development as the sector relies on specific expertise and knowledge for implementing innovations [39]. A skilled workforce could benefit the bioeconomy twofold: by increasing the productivity of the bioeconomy sector and at the same time increasing the demand for more bio-based products. The European Commission [40] emphasizes that: "A well-trained workforce is vital to develop the bioeconomy but there is a growing evidence of a skills gap, with people lacking in specialized knowledge and skills to match the need of new emerging industries and markets and business area"

2. R\&D expense: The Ecological Modernization Theory identifies strategies to overcome the deficiencies in environmental policymaking, which generates supportive conditions and contexts for environmentally sound practices and behaviors on the part of producers and consumers [41]. However, expanding capital intensity coupled with lacking support for piloting and demonstration of sustainable biomass technologies generates hardships for meeting the demand and increases investors' insecurities [42]. Consequently, Scarlet et al. [43] argue that many biotechnological solutions have yet to reach a stage of market maturity where they are economically viable and able to compete with cheap fossil alternatives. Recent years have seen a huge increase in government funding to support the bioeconomy, and the funding opportunities offered for R\&D are particularly important for new and high-risk developments in the field of biotechnology. The study conducted within the BERST project shows that the availability of funding for private companies impacts the development of the bioeconomy [44]. Furthermore, bioeconomy systems development depends on 
policies and public subsidies rather than on completely private initiatives [45], because development of bio-based industries projects, e.g., biorefineries, require a significant initial investment whilst generating unstable revenues that increase financial risk for the private investors [42]. Financial support from the government is a crucial driver for biorefinery development [10].

\subsection{Natural Resource Availability}

Biomass is "the biodegradable fraction of products, waste, and residues from biological origin from agriculture, forestry, and related industries including fisheries and aquaculture, as well as the biodegradable fraction of industrial and municipal waste" [46]. The transition towards a bio-based economy will not only rely on the advancement of biotechnologies to achieve a technical breakthrough and cost-effectiveness but also will depend on the availability of sustainable biomass [43]. In addition, other studies indicate the importance of biomass availability in their analysis of bioeconomy transition and diffusion of biorefineries [1,10,19,20,47].

Biomass is an essential pillar of the bioeconomy as it serves as its main resource [48]. Access to sustainable biomass in sufficient quantity and quality at a competitive price is one of the driving forces for the implementation of biorefinery concepts [10]. In addition, previous studies also conclude that there is competition in the use of biomass, for instance, wood biomass for biorefinery $[15,47]$. When considering both domestic supply and trade, biomass from agriculture counts $65.5 \%$, which is the largest biomass supply sector (in dry matter equivalent), followed by forestry $34.2 \%$ and fishery $0.4 \%$ in the EU 28 [49]. In our analysis, we employ these two predominately used bio-resources from agriculture and forestry for bio-based industries in our analysis.

By investigating the scientific literature (as also summarized in Appendix B Table A1), the relevant conditions we identified within the bioeconomy transition framework for biorefinery development are bioeconomy strategies and initiatives across different levels, bioclusters promoting collaboration and knowledge transfer, intellectual capital (skilled labor along with R\&D expenses), and natural resource availability. These conditions vary between the countries analyzed. Given the different geographical locations of the European countries covered in this study, the contextual condition related to the availability of biomass may differ significantly. Further, bioeconomy strategies and initiatives also differ, as some countries have already set up more coherent bioeconomy strategies to foster the transition to bioeconomy while other countries have not formulated any distinguished strategies. Additionally, we note that EU Renewable Energy Directive (RED II) also plays a role in this transition process, especially in bioenergy production. However, this legislation applies the same for all EU member states; results from the analysis might not reflect this point without variation among the cases. As our aim is to compare cases at the country level, we focus on these conditions for which aggregated data for the largest possible number of cases are publicly available and accessible. In doing so, we hypothesize that if the conditions explained above are fulfilled the advanced biorefinery development is likely to occur. What's more, it is necessary to employ a method that captures the configurations of conditions, including the complex interactions between the conditions according to the aforementioned Complexity Theory [7], to better understand the bioeconomy transition. This cannot be analyzed with regression-based models. Rather, the set-theoretical method is better suited. The methodological framework is presented in detail in the following section.

\section{Material and Method}

\subsection{Material}

We conducted this empirical analysis to explore configurational conditions for bioeconomy development across 20 European countries. Table 1 below indicates the data set we compiled from various data resources. 
Table 1. Conditions and outcome, and the selected indicators for compiling the data set.

\begin{tabular}{|c|c|c|c|}
\hline \multicolumn{2}{|c|}{ Condition Variables } & Indicators & Sources \\
\hline \multicolumn{2}{|c|}{$\begin{array}{l}\text { Bioeconomy strategies and initiatives across different } \\
\text { levels }\end{array}$} & $\begin{array}{l}\text { Presence or absence of: } \\
\text { National bioeconomy strategy; } \\
\text { Regional bioeconomy strategy; } \\
\text { Macro-regional bioeconomy strategy; } \\
\text { Bioeconomy monitoring framework }\end{array}$ & $\begin{array}{l}\text { Knowledge Centre for } \\
\text { Bioeconomy, JRC (2020) [50] }\end{array}$ \\
\hline \multicolumn{2}{|c|}{$\begin{array}{l}\text { Clusters promoting collaboration and bio-based } \\
\text { knowledge transfer }\end{array}$} & $\begin{array}{l}\text { Bioclusters, measured by numbers and } \\
\text { the size of regional bioclusters related } \\
\text { to biorefinery business in the country }\end{array}$ & $\begin{array}{c}\text { European Cluster Collaboration } \\
\text { Platform }{ }^{1}\end{array}$ \\
\hline \multirow[t]{3}{*}{ Intellectual capital } & Human capital & $\begin{array}{l}\text { Tertiary attainment, measured by } \% \text { of } \\
\text { the population }\end{array}$ & Eurostat [51] \\
\hline & R\&D Expenses & $\begin{array}{l}\text { Average public spending in R\&D, \% of } \\
\text { GDP, from } 2010-2019\end{array}$ & Eurostat [52] \\
\hline & Natural resource availability & $\begin{array}{l}\text { Agriculture and forestry biomass } \\
\text { production, measured by tonnes dry } \\
\text { matter per hectare }\end{array}$ & $\begin{array}{l}\text { [49], also available on } \\
\text { Knowledge Centre for } \\
\text { Bioeconomy [53] }\end{array}$ \\
\hline Outcome Variable & $\begin{array}{l}\text { Biorefineries' contribution to } \\
\text { economic development }\end{array}$ & $\begin{array}{l}\text { Turnover of biorefineries sector by } \\
\text { country, \% of the GDP at current prices }\end{array}$ & $\begin{array}{l}\text { [54], also available on European } \\
\text { Commission, JRC [55] }\end{array}$ \\
\hline
\end{tabular}

${ }^{1}$ The data on clusters information were first extracted from the website (see the Supplementary Materials), and then the intensity of the network was measured according to the size and number of regional bioclusters.

Bioeconomy strategies and initiatives across different levels $\left(B E \_S\right)$ : we assessed this condition from 4 dimensions: national, regional, macro-regional bioeconomy strategies and the bioeconomy monitoring framework. This article did not seek to compare the objectives and assess the implementation of bioeconomy strategies but attempted to relate the presence or absence of bioeconomy strategies at different levels to the respective transition dynamics taking place in the biorefinery sector.

Clusters promoting collaboration and bio-based knowledge transfer (Cluster_Int): study on the relationship between bioclusters and success of the bioeconomy has considered cluster size, cluster management, and cluster governance [44]. We acknowledge that these perspectives are essential to investigate this causal relationship. For the purpose of our analysis, it is sufficient to look at the network intensity of existing bioclusters whose services and products are linked to the development of biorefineries in EU countries. This is supported by [27] that network intensity of bioclusters contributes to the knowledge accumulation and learning. The intensity of the network was measured by the cluster composition, including SMEs (including start-ups), large companies, research organisations, universities, technology centers, civil society members, and other ecosystem actors.

The representative indicators on Intellectual capital: we classified the intellectual capital on education attainment and R\&D spending as indicated by [38]. Thus, they are persons with tertiary education (EDU_Tert) (level 5-9), from age 15-64 years, measured \% of the population and average R\&D expenses (RD_Exp) measured by \% of GDP from 2010 to 2019 among the cases.

Nature resource availability (Biomass_P): biomass production by biomass type, mainly on agriculture and forestry wood biomass, which was measured by tonnes dry matters per hectare (it was calculated by the total sum of biomass from agriculture and forestry/total available agriculture and forestry land). Data for the total hectares of agriculture and forestry land was from [56].

The outcome variable is the contribution of biorefineries on economic development (Bio_Dev). It was measured by the turnover of bio-based sectors, \% of the GDP from 2009 to 2017. The definition of a biorefinery is built on complex arrangements of processes for converting different types of biomass by applying various types of conversion technologies, and generating bioenergy and a variety of bio-based products $[10,11]$. Thus, using the method proposed by [57], we selected bio-based sectors that were closely related to 
biorefineries (manufacturing of bio-based chemicals, pharmaceuticals, plastic and rubber composed through manufacture of chemicals (excluding biofuels); manufacture of liquid biofuel composed through manufacture of bioethanol and manufacture of biodiesel; and production of bioelectricity). However, we excluded the traditional products like paper, as concluded by [16], that the future for biorefineries should focus on new businesses and new products (e.g., wood-based biofuels).

Table 2 provides the summary statistics for the data set compiled. The cases in our analysis contain 20 European countries: Austria, Belgium, Bulgaria, Czech Republic, Denmark, Finland, Germany, France, Italy, Netherlands, Greece, Portugal, Romania, Hungary, Slovakia, Spain, Sweden, Lithuania, Latvia, and Poland. These cases have wide geographical coverage, including Western, Northern, Southern, as well as Central and Eastern European countries.

Table 2. Summary statistics of the data set.

\begin{tabular}{ccccccc}
\hline Variables & Mean & Std. Dev & Minimum & Maximum & No. Cases & Missing \\
\hline BE_S & 0.55 & 0.35 & 0 & 1 & 20 & 0 \\
Cluster_Int & 113.45 & 82.12 & 29 & 339 & 20 & 0 \\
RD_Exp & $1.721 \%$ & $0.916 \%$ & $0.467 \%$ & $3.249 \%$ & 20 & 0 \\
EDU_Tert & $29.86 \%$ & $6.798 \%$ & $16.2 \%$ & $38.7 \%$ & 20 & 0 \\
Biomass_P & 38.624 & 16.212 & 12.334 & 67.092 & 20 & 0 \\
Bio_Dev & $1.34 \%$ & $1.22 \%$ & $0.303 \%$ & $5.28 \%$ & 20 & 0 \\
\hline
\end{tabular}

Source: own calculation, where $B E \_S=$ Bioeconomy strategies across different levels; Cluster_Int = Intensity of regional clusters, measured by the composition of the cluster; RD_Exp $=$ R\&D expenses, \% of GDP; EDU_Tert $=$ human capital, measured by the proportion of the population who have the tertiary education; Biomass_P $=$ agriculture and forestry biomass production; Bio_Dev $=$ biorefineries sector's contribution to the economic development.

\subsection{Fuzzy-Set Qualitative Comparative Analysis (fs QCA)}

This study draws on fuzzy-set qualitative comparative analysis (fsQCA). Qualitative comparative analysis is a set-theoretic method that empirically explores the relationships between the outcome of interest and all possible combinations of its conditions. Configurational causation combines various causal conditions rather than one single condition for explaining the causes of outcomes [58]. In recent years, there has been a considerable interest in the application of set-theoretic methods to study bioeconomy development. Such cases include investigation on the configurational conditions for the EU biofuels directive implementation [59], the performance of biotechnology firms [60], and the bioeconomy policies objectives and sustainable goal [5].

We employ the fsQCA method because the technique combines both qualitative and quantitative methodologies, which offers the convenience for researchers to investigate the causal complexities [61]. This method is a case-oriented approach to examine the cases configurationally, and it can be applied on a small to medium sample analysis while allowing for a comparison that delineates the complexity of the cases [62]. Through the "fuzzified" conception, fuzzy membership scores allocate cases in multidimensional vectors. This is not a simple sorting of cases into subpopulations, therefore, it adds the sophistication and richness for studying cases as configurations [61]. Given that our sample data was limited to 20 European countries, this method for conducting the analysis became increasingly important. Figure 1 below illustrates the steps for performing fsQCA [63]. 


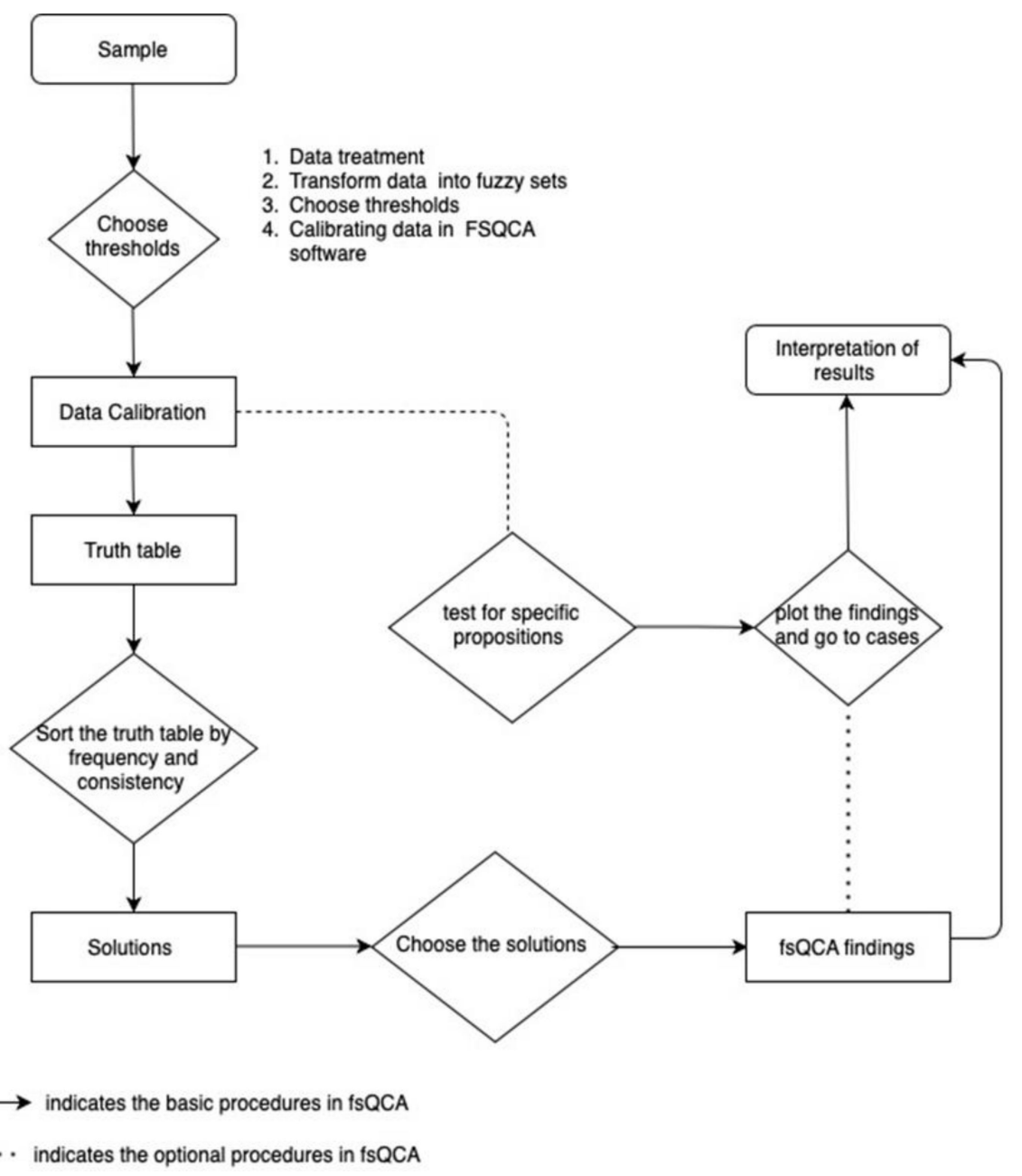

Figure 1. Basic procedures of conducting fsQCA, Source: adapted from Pappas and Woodside [63].

For the calibration process, we followed the steps outlined by Ragin [64]. Each selected case in the study received a score between 0 and 1 ; the value 0.0 indicates the full out of the target set and 1.0 means fully in the target set. Further, the scores could be broken down into different scales. The calibration scores on qualitative data should be based on substantive knowledge about the cases $[65,66]$. Such knowledge can stem from both primary qualitative data, for instance government documents, and secondary literature [67]. When it comes to the calibration of quantitative data, the first step of data querying is required in order to assess the distribution of the data. The calibration on quantitative data is less complex, because numbers are more easily inspected for clustering than qualitative descriptions [67].

The fuzzy-set QCA developed by [68] proved to be a useful tool (this is available from: https:/ / www.socsci.uci.edu/ cragin/fsQCA/software.shtml (accessed on 10 December 2020)) for screening and identifying the right combinations of conditions. Datasets on bioclusters, public funding on R\&D, resource availability, human capital, and biorefineries' contribution to economic development are both quantitative data sets; therefore, the method for calibrating them is less complicated. This involved using the function "COMPUTE" in the software with calibrate $(\mathrm{x}, \mathrm{n} 1, \mathrm{n} 2, \mathrm{n} 3)$. Here, " $\mathrm{n}$ " is the variable to be calibrated, " $\mathrm{n} 1$ " is the maximum value in this data set, " $\mathrm{n} 3$ " is the minimum score in the data set respectively and " 2 " is the cutoff point using the respective value of the selected indicators on EU 27, since our cases are among the European countries.

Once all of the conditions are calibrated, necessary conditions should be analyzed before constructing the truth tables [66]. A causal condition is necessary when the outcome is the condition's subset. With the recommendation, if the consistency score is smaller than 
0.9 , a condition will not be considered as a necessary condition [69]. Table 3. shows the results of the necessity analysis for the outcomes. The highest consistency score in our case is 0.89 , which is smaller than 0.9 . It indicates that no single condition is qualified for a necessary condition, and further analysis on sufficient conditional configuration is required. We then constructed the truth table generated by the software fsQCA and followed the manual provided by Ragin [64]. We set the consistency level $\geq 0$.9. From the truth table, we further performed the standard analysis by setting the conditions as either presence or absence. The conditions analyzed were the nation's coherent bioeconomy strategy $\left(B E \_S\right)$, regional bioclusters for collaboration and knowledge transfer (Clsuter_Int), natural resource endowment (Biomass_P), educational attainment (EDU_Tert), and public spending on $R \& D\left(R D \_E x p\right)$. The outcome variable was the contribution of biorefineries for economic development (Bio_Dev), which was measured by the turnover of bio-based sectors, $\%$ of the GDP from 2009 to 2017. We run the model: Bio_Dev $=\mathrm{f}($ BE_S, Biomass_P, Cluster_Int, $R D \_E x p, E D U \_$Tert) with the algorithm of Quine-McCluskey and set the frequency cutoff at 1 , as the sample size was relatively small. This is supported by Capatina et al. [70] that frequency cutoff can be set at 1 for a small-N. A small-N indicated the sample size is smaller than 50 [71]. With a sample size of 20, the choice on frequency cutoff at 1 was appropriate. There is a debate in the QCA literature on the selection of a proper solution (complicated solution, intermediate solution, or parsimonious solution) to interpret; we tend to acknowledge the efforts from Ragin [65]. Therefore, we presented the intermediate solutions (Table 4) in this study.

Table 3. Summary of necessary conditions relative to advanced and slow biorefinery development.

\begin{tabular}{ccccc}
\hline Outcomes & \multicolumn{2}{c}{ Bio_Dev } & \multicolumn{2}{c}{$\sim$ Bio_Dev } \\
\hline Conditions & Consistency & Coverage & Consistency & Coverage \\
\hline BE_S & 0.783619 & 0.608316 & 0.514382 & 0.577947 \\
$\sim$ BE_S & 0.457213 & 0.394515 & 0.652284 & 0.813291 \\
EDU_Tert & 0.827628 & 0.617138 & 0.596447 & 0.642662 \\
$\sim$ EDU_Tert & 0.520782 & 0.471761 & 0.644670 & 0.843854 \\
Biomass_P & 0.536675 & 0.468517 & 0.681895 & 0.860182 \\
$\sim$ Biomass_P & 0.839853 & 0.636284 & 0.578680 & 0.643462 \\
Cluster_Int & 0.825153 & 0.855513 & 0.423258 & 0.634981 \\
$\sim$ Cluster_Int & 0.647922 & 0.437655 & 0.892147 & 0.881891 \\
RD_Exp & 0.856968 & 0.760304 & 0.440778 & 0.565076 \\
$\sim$ RD_Exp & 0.509780 & 0.386827 & 0.813029 & 0.891466 \\
\hline
\end{tabular}

Note: $\sim$ means the negation of the conditions, source: own calculation.

Table 4. Configurations for advanced and slow biorefineries development. Intermediate solutions.

\begin{tabular}{|c|c|c|c|c|c|}
\hline Configurations & 1 & 2 & 3 & 4 & 5 \\
\hline & $\begin{array}{l}\text { Austria, } \\
\text { Germany }\end{array}$ & $\begin{array}{l}\text { Finland, } \\
\text { Netherlands, } \\
\text { Sweden, } \\
\text { France }\end{array}$ & Italy, Spain & $\begin{array}{l}\text { Greece, } \\
\text { Hunagry, } \\
\text { Lithuania, } \\
\text { Portugal }\end{array}$ & $\begin{array}{l}\text { Czechia, } \\
\text { Slovakia, } \\
\text { Bulgaria, } \\
\text { Romania }\end{array}$ \\
\hline $\begin{array}{l}\text { Outcomes } \\
\text { Conditions } \\
\end{array}$ & \multicolumn{3}{|c|}{ Bio_Dev } & \multicolumn{2}{|c|}{ Bio_Dev } \\
\hline$B E \_S$ & 0 & O & O & (-) & () \\
\hline EUD_Tert & - & 0 & - & - & (2) \\
\hline Biomass_P & 0 & (2) & () & () & 0 \\
\hline Cluster_Int & 0 & - & 0 & () & () \\
\hline$R D \_E x p$ & 0 & O & () & () & - \\
\hline Consistency cutoff & \multicolumn{3}{|c|}{0.93} & \multicolumn{2}{|c|}{0.923} \\
\hline Frequency cutoff & \multicolumn{3}{|c|}{1} & \multicolumn{2}{|c|}{1} \\
\hline
\end{tabular}


Table 4. Cont.

\begin{tabular}{cccccc}
\hline Outcomes & \multicolumn{3}{c}{ Bio_Dev } & \multicolumn{2}{c}{$\sim$ Bio_Dev } \\
Conditions & & 0.9063 & 0.0996 & 0.9838 \\
Consistency & 0.9286 & 0.9093 & 0.4609 & 0.3494 & 0.4094 \\
Raw Coverage & 0.3496 & 0.5636 & 0.1641 & 0.2140 \\
Unique Coverage & 0.0746 & 0.1920 & 0.1039 & 0.1641 \\
\hline Solution Coverage & & $\mathbf{0 . 7 6 2 8}$ & & \multicolumn{2}{c}{$\mathbf{0 . 7 4 8 5}$} \\
\hline Solution & & $\mathbf{0 . 9 2 2 9}$ \\
Consistency & & & & \multicolumn{2}{c}{} \\
\hline
\end{tabular}

Note: $\bigcirc$ indicates the presence of the condition; () means the absence of the condition. The " - " cell indicates the causal recipe does not include this condition.

\section{Results}

According to Ragin [72], "'consistency' assesses the degree to which a subset relation has been approximated, and 'coverage' measures the empirical relevance of a consistent subset." He further suggests that the consistency scores should be as close to 1.0 as possible, which indicates a perfect consistency. However, when the consistency scores are below 0.75 , it is challenging to interpret the result that a causal or a combination of causal relations exists in the observed cases [72]. From our truth table analysis, it was interesting to note that each causal recipe's consistency score was larger than the threshold 0.75. Our findings appeared to be well substantiated by Ragin's suggestion. Hence, we could claim that the configurations yielded from the analysis are informative. Table 4 . illustrates the causal paths for more advanced biorefineries development (left side, configurations 1-3) and slow biorefineries development (configurations 4-5) among the cases.

Overall, three configurations (1-3) sufficiently explain the advanced development in biorefinery sectors. They count for $85 \%$ of the relevance and cover $76 \%$ of the total cases. In particular, Configuration 1 shows the pronounced development correlates with the coherent bioeconomy strategies, abundant biomass supply, large network intensity of regional bioclusters and sufficient public spending on R\&D. This pattern can be found in Austria and Germany. In addition, Configuration 2 indicates that with the absence of abundance biomass supply, coherent bioeconomy strategies and high level of intellectual capital (high proportion of population with tertiary education and sizable R\&D spending) could contribute to the advancement of bioeconomy. Sample cases include Sweden, Finland, Netherlands, and France.

By contrast, those cases stagnated in their biorefinery development were associated with a lack of coherent bioeconomy strategies implemented amongst different levels, low proportion of skilled labor, low network intensity of regional bioclusters, and insufficient public spending. This pattern exists in Greece, Portugal, Hungary, and Lithuania, as shown in Configuration 4, whereas, Configuration 5 demonstrates some Eastern European countries, e.g., Czech Republic, Slovakia, Bulgaria, and Romania, have sufficient biomass production, but their biorefinery development has been hindered by the lack of coherent bioeconomy strategies, low level of intensity of regional bioclusters, and lack of skilled labor.

\section{Discussion}

A main finding from our analysis indicates the importance of coherent strategies across different levels; slow development in the sector and stagnated diffusion of biorefineries within a country correlates with poor or no strategy. The pattern exists mostly in the Central and Eastern European countries such as Romania, Slovakia, Bulgaria, Hungary, and Czech Republic. Our finding corroborates with a previous study analyzing the bioeconomy development in Czech Republic [3]. The authors conclude that no targeted national strategies have been initiated in Czech Republic and other Eastern European countries. At the national level, implementation of strategies would include coordinated measures, for 
instance, building up more governmental support, increasing stakeholders' participation, and strengthening the research and technology development.

With regard to the macro-regional bioeconomy strategy, one of the EU funded projects BIOEAST (this Central and Eastern European Initiative aims for a knowledge-based agriculture, aquaculture, and forestry in bioeconomy, and offers a political commitment to share strategic research and innovation framework for the transition to sustainable bioeconomies in this region. https:/ /bioeast.eu/home/ (accessed on 15 February 2021)) has caught our attention as an opportunity for improvement whereby the initiatives address strategic research and innovation framework for the transition to a bioeconomy. Interestingly, the project targets many of the countries which showed lagging biorefineries development in our study. We acknowledge that this political initiative is crucial to the development as it enhances international cooperation in addition to establishing the framework for the dissemination of innovation across nations [3]. Still, this approach could benefit from incorporating more national or regional measures. As the results suggest, a national bioeconomy strategy with clear objectives is a major determinant for a successful transition towards an envisioned bioeconomy outcome. However, there is the caveat that an effective bioeconomy strategy takes into consideration country-specific factors such as geographic locations, biomass availability and economic condition [4]. Moving towards this aim, recent years have seen more focus on business advantages at the regional level accompanied by increased mobilization of regional actors. Each region has its own advantages and resources, and these are crucial factors to stimulate the innovation capabilities of that region [73]. Thus, a country's bioeconomy benefits more from the development of regional strategies based upon the particular strengths and capabilities of the respective region [25]. When comparing with more advanced countries in terms of their biorefinery development as shown in our results, they already have adopted a more coherent bioeconomy strategy at national, regional, and macro-regional levels. Furthermore, they are in the process of developing a bioeconomy monitoring system to ensure a sustainable development within the bioeconomy sectors. Lastly, a well-structured bioeconomy strategy has to include the establishment of a monitoring system. The fact that all the advanced bioeconomies have a monitoring system in place, while those with moderate to poor bioeconomies do not, conveys the significance of such a system and its potential to provide critical feedback. Adopting a monitoring system encourages data collection and sharing to close the gaps at the national and supranational level; this allows for a more comprehensive analysis of the bioeconomy transition [74].

Amongst all the aforementioned conditions, the coordinated strategies across different levels is the most common factor amongst the cases (e.g., Germany, France, Finland, Austria, Netherlands, Sweden), which are classified as having a more advanced bioeconomy. Conversely, when more fragmented approaches were implemented in the absence of a well-defined strategy, the country's bioeconomy experienced diversified incentives on biomass use, opposition to private investment, and a decline in R\&D for biotechnologies, our finding is in line with [1]. Still, a growing number of countries in Europe are mobilizing their resources to implement a national strategy for the bioeconomy. Slovakia and Portugal are among those improving their strategy to align the national agenda with the interests of bioeconomy sectors.

Furthermore, one of the causal paths yielded in our analysis is the high level of network intensity of regional clusters engaged in the bioeconomy, sufficient supply of biomass, sizable public spending on R\&D, alongside the coherent bioeconomy strategies across different levels. This causal recipe is a sufficient condition to explain the more advanced implementation and diffusion of biorefineries among the cases in this study. One of the advantages of establishing regional bioclusters is to facilitate knowledge transfer and to enhance the innovation between the local actors. Further, it supports the deployment of that knowledge and innovation to create bio-based products that will strengthen regional economic development and thus employment $[29,30]$. Without this network of agents interacting in this economic and industrial arena, the diffusion of local knowledge and 
innovation may be interrupted. Therefore, connecting with appropriate local stakeholders to foster innovation development can reduce the transaction cost and coordination cost. Consequently, efforts to build up regional actor networks should increase. It is crucial to promote policy instruments (e.g., tax reduction) for the development of bioclusters in the regions [29]. In addition, sufficient agriculture and wood biomass supply alone does not make it more feasible to develop their biorefineries sector. Some Eastern European countries such as Bulgaria, Romania, and the Czech Republic have relatively sufficient biomass; however, the combination of a shortage of skilled labor, a lack of regional bioclusters to promote biorefinery businesses, and less coordinated bioeconomy strategies across different levels makes their biorefineries sector far less advanced. What is more, as sustainability is an important consideration, the biomass supply should avoid competition with agricultural land use, food security, or environmental conservation. This requires new approaches to improve the potential of sustainable biomass supply. One example is the integrated value chain approach [45]. The EU Renewable Energy Directive (RED II) and EU bioeconomy strategies both emphasize the sustainable management of biomass and landscape. Using alternative biomass and grass from grasslands provide optimization potentials and sustainable practices compared to corn-based practice for the bioenergy supply chain [75]. A new EU initiative (GO-GRASS project, https: / /www.go-grass.eu/ (accessed on March 1, 2021)) is calling for utilizing the potentially underused biomass from grassland through the development of new technologies and innovative grass-based value chains. However, there are also concerns on sustainability issues of biomass trading under the RED II framework, because each EU country could define its energy sector, and the cost for biomass from the non-feed or food market varies between the member states [76]. This factor could lead to potential hindrance for biorefineries development in the future.

Lastly, another salient configuration that appears to promote bioeconomy development is the presence of a high percentage of skilled workers alongside sufficient public spending on R\&D, and well-coordinated bioeconomy strategies across different levels. Countries like Finland and Sweden, with a high level of intellectual capital (a large proportion of the population with tertiary education and a higher government budget on R\&D) generates benefits on the development of biorefineries. Our findings corroborate with the previous study that intellectual capital has positive implications on bioeconomy development among the European countries and there is evidence that tertiary education has a major importance on the bioeconomy, while public financial support for R\&D generates positive bioeconomy outcomes [38]. In addition, a lower government budget on R\&D could generate constraints on the development of biorefineries [10]. By contrast, lack of these factors combined together could explain the current slow development of the biorefineries in the countries, such as Greece, Hungary, Portugal, and Lithuania. It suggests that policies and regulations need to be implemented to redirect the funding opportunities on R\&D and stimulate the motivations from business sectors to engage in the biorefineries sector. Meanwhile, it is also crucial to promote bioeconomy education to recruit a sufficient workforce as the bioeconomy grows.

\section{Conclusions}

The study aims to provide insights about the specific configurational conditions that indicate current bioeconomy outcomes among European countries, especially in regards to developing their biorefinery industry. Unlike previous empirical studies assessing the factors related to the diffusion and implementation of biorefineries, we adopt the settheoretical method to conduct a cross-national comparison and illustrate the configurational conditions that offer an explanation for the variation in biorefinery development across Europe. Our analysis points out the configurations for the pronounced development in bioeconomy and diffusion of biorefineries in European countries: (1) Coherent bioeconomy strategies, a high level of intensity of regional bioclusters, rich biomass supply, and sizable public spending on R\&D, (2) high level of intellectual capital (sufficient public spending on $R \& D$, and a high proportion of the population with tertiary education) together with 
coherent bioeconomy strategies across different levels. By comparison, the transformation to a bioeconomy appears to be constrained by the current low level of intellectual capital (low proportion of skilled labor and insufficient public spending on R\&D), low level of network intensity together with the lack of coherent bioeconomy strategies.

The implications of these results can be applied to policy recommendations. First, countries should align their national interest in the field of bioeconomy by developing more coherent strategies to facilitate the development. Second, the results emphasize the importance of motivating the business sector to engage with the bioeconomy sectors through implementing policies and regulations that redirect funding opportunities towards R\&D. Related to this, increased efforts should be directed to strengthening regional actor networks that help facilitate innovation development. Last but not least, the sustainability of biomass supply should also not be overlooked. Avoiding conflicts with land use and other agricultural activities is fundamental to bioeconomy development. When addressing the gap created by a biomass supply that is not sustainable, new biotechnologies that process potentially underused biomass in conjunction with novel value chains could prove beneficial. More deliberate policy related to sustainable biomass use should be implemented with the aim to promote the renewable energy transition while not hindering the biorefineries development. Another area of improvement is the promotion of bioeconomy education to recruit a sufficient workforce as the bioeconomy grows. With regards to country specific recommendations, the presence of varying configurational conditions, in addition to natural resources and economic capacity, means the biorefineries tend to develop at different rates according to the state of the aforementioned conditions.

Although this study addresses the gaps in the literature, we are aware our research has some limitations. Firstly, we acknowledge that the bioeconomy sector is a complex system and its transition is a highly diverse process with various driving factors and conditions as described in our methodology section. Due to the fsQCA model restrictions imposed by a small sample of 20 cases, the scope of the study has been limited to 5 conditions to maintain a balance between parsimony and complexity. Further studies could investigate more alternative conditions to determine the sufficient conditions for the bioeconomy development within a broader scope. Finally, the study uses the biorefineries' contribution to economic development as an outcome variable and indicator of bioeconomy development. For future work, we recommend expanding the analysis to look at other more specific outcome variables, for example, in relation to job creation and climate change mitigation.

Supplementary Materials: The following are available online at https:/ / www.mdpi.com/article/10 .3390/su14010090/s1, Regional Bioclusters.

Author Contributions: Z.D. and P.G. developed the ideas and concept, drafted the manuscript. P.G. developed the conceptual framework. Z.D. collected the data and conducted the analysis. Z.D. and P.G. visualized the results. All authors have read and agreed to the published version of the manuscript.

Funding: This work was supported by the European Union's Horizon 2020 research and innovation program [N862674].

Institutional Review Board Statement: Not applicable.

Informed Consent Statement: Not applicable.

Data Availability Statement: The details of data used for the analysis, including data sources, are listed in Table 2.

Acknowledgments: We thank Charity Young for her efforts in proofreading for this paper and two anonymous reviewers for their insightful comments that greatly improved the manuscript. The publication of this article was funded by the Open Access Fund of the Leibniz Association.

Conflicts of Interest: The authors report no declarations of interest. 


\section{Appendix A}

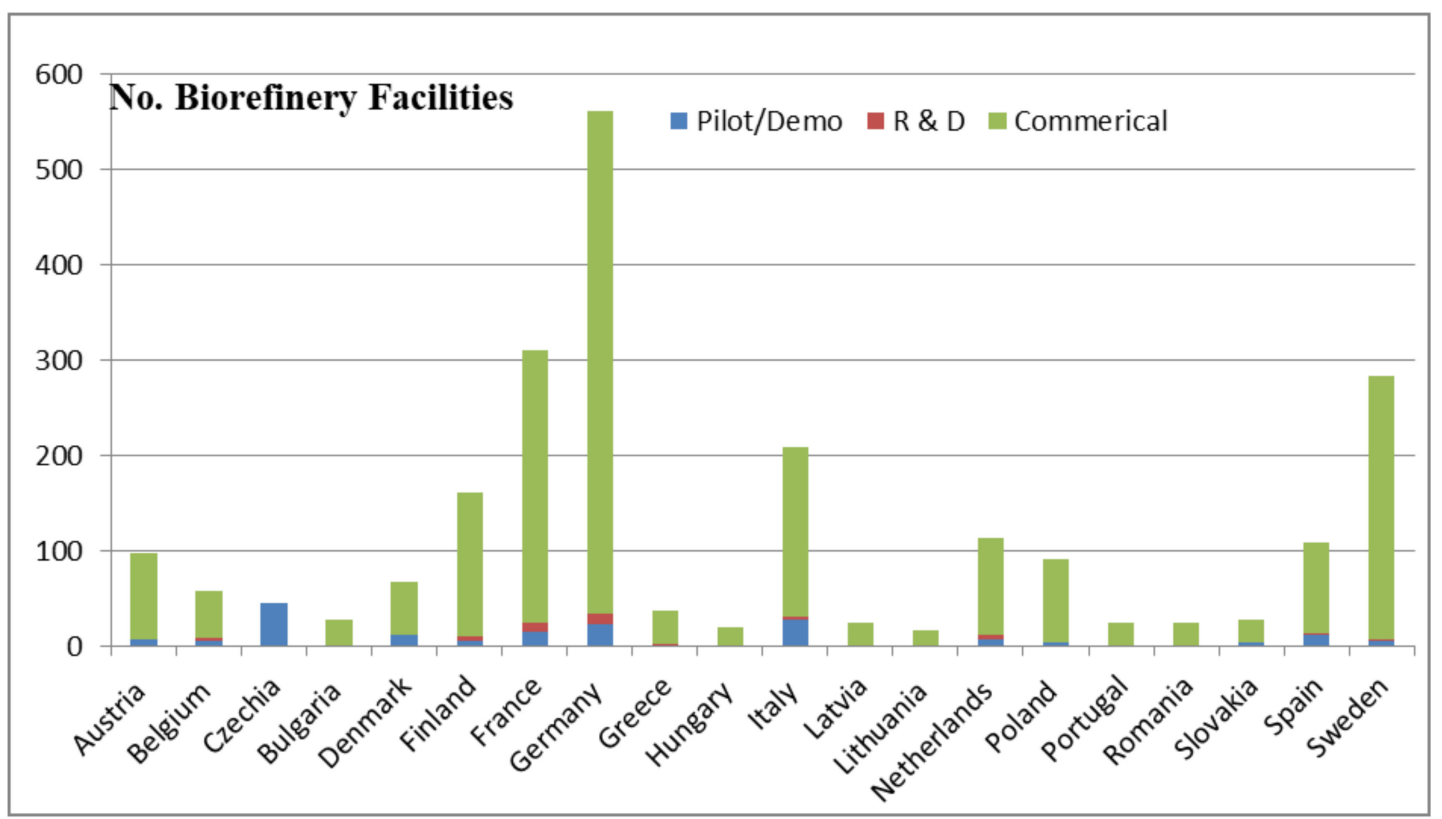

Figure A1. The distribution of biorefineries among 20 European countries, including the pilot/demo, R\&D, and commercial plants (up to 2017), Source: own illustration and data source from [14].

\section{Appendix B}

Table A1. List of studies exploring factors that drive the bioeconomy transition and the diffusion of biorefineries.

\begin{tabular}{|c|c|c|c|}
\hline Authors & Title & Source & Covered Topic \\
\hline Hetemäki et al., 2017 [77] & $\begin{array}{l}\text { Leading the way to a European } \\
\text { circular bioeconomy strategy }\end{array}$ & $\begin{array}{l}\text { European Forest } \\
\text { Institute }\end{array}$ & EU bioeconomy strategy \\
\hline Lühmann, 2020 [78] & $\begin{array}{l}\text { Whose European bioeconomy? } \\
\text { Relations of forces in the shaping of } \\
\text { an updated EU bioeconomy strategy }\end{array}$ & $\begin{array}{l}\text { Journal of } \\
\text { Environmental } \\
\text { Development }\end{array}$ & EU bioeconomy strategy \\
\hline Staffas et al., 2013 [2] & $\begin{array}{l}\text { Strategies and policies for the } \\
\text { bioeconomy and biobased economy: } \\
\text { An analysis of official national } \\
\text { approaches }\end{array}$ & Sustainability & $\begin{array}{l}\text { National bioeconomy } \\
\text { strategy }\end{array}$ \\
\hline Dietz et al., 2018 [1] & $\begin{array}{l}\text { Governance of the bioeconomy: A } \\
\text { global comparative study of national } \\
\text { bioeconomy strategies }\end{array}$ & Sustainability & $\begin{array}{l}\text { National bioeconomy } \\
\text { strategy }\end{array}$ \\
\hline Kardung et al., 2021 [20] & $\begin{array}{l}\text { Development of the circular } \\
\text { bioeconomy: Drivers and indicators }\end{array}$ & Sustainability & Bioeconomy monitoring \\
\hline Robert et al., 2020 [74] & $\begin{array}{l}\text { Development of a bioeconomy } \\
\text { monitoring framework for the } \\
\text { European Union: An integrative and } \\
\text { collaborative approach }\end{array}$ & $\begin{array}{l}\text { Journal of New } \\
\text { Biotechnology }\end{array}$ & $\begin{array}{l}\text { Bioeconomy monitoring } \\
\text { framework }\end{array}$ \\
\hline Jander et al., 2020 [19] & $\begin{array}{l}\text { Monitoring bioeconomy transitions } \\
\text { with economic-environmental and } \\
\text { innovation indicators: Addressing } \\
\text { data gaps in the short term }\end{array}$ & Sustainability & $\begin{array}{l}\text { Bioeconomy monitoring } \\
\text { framework }\end{array}$ \\
\hline
\end{tabular}


Table A1. Cont.

\section{Authors}

De Besi and McCormick, 2015 [25]

Lange et al., 2015 [82]

Wilde and Hermans, 2021 [83]

Hermans, 2018 [30]

Lauka et al., 2019 [48]

Lewandowski, 2015 [45]

Tiron-Tudor et al., 2018 [86]

Vătămănescu et al., 2018 [87]
Title

Knowledge-based greening as a new development: agroecological utopia or revolution? bioeconomy strategy for

\section{Source}

Book: Law and agroecology (pp. 439-450)

Towards a Bioeconomy in Europe. National, Regional and Industrial Strategies

Policy dialogue on a bioeconomy for sustainable development in the Baltic Sea region

Strategies for greening the economy in three Nordic countries

Development of the Nordic Bioeconomy

Deconstructing the attractiveness of biocluster imaginaries

Introducing a multiscalar framework for biocluster research: A meta-analysis

Sustainability

Regional bioeconomy strategy

Macro-regional

bioeconomy strategy

Environment Institute $\quad \begin{array}{r}\text { bioeconomy strategy } \\ \text { (Baltic region) }\end{array}$
Macro-regional

Environmental Policy bioeconomy strategy and Governance

(Nordic region)

Macro-regional bioeconomy strategy (Nordic region)

Biocluster and

Journal of

Environmental Policy and Planning

bioeconomy development

Biocluster and

Sustainability bioeconomy development

The potential contribution of transition theory to the analysis of bioclusters and their role in the transition to a bioeconomy

Biofuels, Bioproducts, and Biorefining

Biocluster and bioeconomy development

Biocluster and bioeconomy development

Regional biotechnology-The EU biocluster study

Journal of Commercial Biotechnology

The role of biomass and bioenergy in a future bioeconomy: Policies and facts

Journal of

Environmental

Development

When Bioeconomy Development Becomes a Biomass Energy

Journal of

Environmental and Competitor
Role of biomass in bioeconomy development

Biomass for bioeconomy development (wood biomass)

Role of biomass in bioeconomy development supply in a growing bioeconomy

Global Food Security

The management of agricultural waste biomass in the framework of circular economy and bioeconomy: An opportunity for greenhouse agriculture in Southeast Spain

Global bioeconomy in the conflict between biomass supply and demand

The role of universities in consolidating intellectual capital and generating new knowledge for a sustainable bioeconomy

A demand-side perspective of bioeconomy: the influence of online intellectual capital on consumption
Agricultural biomass for bioeconomy development

Agronomy
Industrial Biotechnology

Amfiteatru Economic
Biomass for bioeconomy development (global perspective)

Intellectual capital for bioeconomy development
Intellectual capital for

Amfiteatru Economic development 
Table A1. Cont.

\begin{tabular}{|c|c|c|c|}
\hline Authors & Title & Source & Covered Topic \\
\hline Boljanovic et al., 2018 [34] & $\begin{array}{l}\text { Knowledge-based bioeconomy: The } \\
\text { use of intellectual capital in food } \\
\text { industry of Serbia }\end{array}$ & Amfiteatru Economic & $\begin{array}{c}\text { Intellectual capital for } \\
\text { bioeconomy } \\
\text { development }\end{array}$ \\
\hline Gârdan et al., 2018 [35] & $\begin{array}{l}\text { Bioeconomy development and use of } \\
\text { intellectual capital for the creation of } \\
\text { competitive advantages by SMEs in } \\
\text { the field of biotechnology }\end{array}$ & Amfiteatru Economic & $\begin{array}{c}\text { Intellectual capital for } \\
\text { bioeconomy } \\
\text { development }\end{array}$ \\
\hline Nedelea et al., 2018 [88] & $\begin{array}{l}\text { Modeled interdependencies between } \\
\text { intellectual capital, circular economy } \\
\text { and economic growth in the context } \\
\text { of bioeconomy }\end{array}$ & Amfiteatru Economic & $\begin{array}{l}\text { Intellectual capital for } \\
\text { bioeconomy } \\
\text { development }\end{array}$ \\
\hline Anghel et al., 2019 [38] & $\begin{array}{l}\text { Bioeconomy credentials and } \\
\text { intellectual capital: a comparative } \\
\text { modeling approach for the EU-13 } \\
\text { and EU-15 }\end{array}$ & $\begin{array}{l}\text { Economic } \\
\text { research-Ekonomska } \\
\text { istraživanja }\end{array}$ & $\begin{array}{c}\text { Intellectual capital for } \\
\text { bioeconomy } \\
\text { development }\end{array}$ \\
\hline
\end{tabular}

\section{References}

1. Dietz, T.; Börner, J.; Förster, J.J.; von Braun, J. Governance of the bioeconomy: A global comparative study of national bioeconomy strategies. Sustainability 2018, 10, 3190. [CrossRef]

2. Staffas, L.; Gustavsson, M.; McCormick, K. Strategies and policies for the bioeconomy and bio-based economy: An analysis of official national approaches. Sustainability 2013, 5, 2751-2769. [CrossRef]

3. Hájek, M.; Holecová, M.; Smolová, H.; Jeřábek, L.; Frébort, I. Current state and future directions of bioeconomy in the Czech Republic. New Biotechnol. 2021, 61, 1-8. [CrossRef] [PubMed]

4. Bosman, R.; Rotmans, J. Transition governance towards a bioeconomy: A comparison of Finland and The Netherlands. Sustainability 2016, 8, 1017. [CrossRef]

5. Christensen, L.D. When Bioeconomy Policy Objectives (Fail To) Overlap: Rethinking the Analysis of Necessity to Detect Causal Interdependencies among Sustainable Development Goals in the Nordic Bioeconomy Strategy. COMPASSS Work. Pap. $2019,93$. Available online: http:/ /www.compasss.org/wpseries/Christensen2019.pdf (accessed on 1 January 2021).

6. Maciejczak, M. Bioeconomy as a Complex Adaptive System of Sustainable Development. J. Int. Bus. Res. Mark. 2017, 2, 7-10. [CrossRef]

7. Urry, J. The complexity turn. Theory Cult. Soc. 2005, 22, 1-14. [CrossRef]

8. OECD. The Bioeconomy to 2030: Designing a Policy Agenda; OECD Publishing: Paris, France, 2009; pp. 181-182.

9. Hansen, T.; Coenen, L. Unpacking resource mobilisation by incumbents for biorefineries: The role of micro-level factors for technological innovation system weaknesses. Technol. Anal. Strateg. Manag. 2017, 29, 500-513. [CrossRef]

10. Brunnhofer, M.; Gabriella, N.; Schöggl, J.P.; Stern, T.; Posch, A. The biorefinery transition in the European pulp and paper industry-A three-phase Delphi study including a SWOT-AHP analysis. For. Policy Econ. 2020, 110, 101882. [CrossRef]

11. Näyhä, A.; Hetemäki, L.; Stern, T. New Product Outlook. In Future of the European Forest-Based Sector: Structural Changes Towards Bioeconomy; What Science Can Tell Us 6; European Forest Institute: Joensuu, Finland, 2014; pp. 43-54.

12. Ubando, A.T.; Felix, C.B.; Chen, W.H. Biorefineries in circular bioeconomy: A comprehensive review. Bioresour. Technol. 2020, 299, 122585. [CrossRef]

13. Parajuli, R.; Dalgaard, T.; Jørgensen, U.; Adamsen, A.P.S.; Knudsen, M.T.; Birkved, M.; Gylling, M.; Schjørring, J.K. Biorefining in the prevailing energy and materials crisis: A review of sustainable pathways for biorefinery value chains and sustainability assessment methodologies. Renew. Sustain. Energy Rev. 2015, 43, 244-263. [CrossRef]

14. Parisi, C.; Baldoni, E.; M'barek, R. Bio-Based Industry and Biorefineries. European Commission, Joint Research Centre (JRC). Available online: http:/ / data.europa.eu/89h/ee438b10-7723-4435-9f5e-806ab63faf37 (accessed on 20 January 2021).

15. Hellsmark, H.; Mossberg, J.; Söderholm, P.; Frishammar, J. Innovation system strengths and weaknesses in progressing sustainable technology: The case of Swedish biorefinery development. J. Clean. Prod. 2016, 131, 702-715. [CrossRef]

16. Näyhä, A.; Pesonen, H.L. Diffusion of forest biorefineries in Scandinavia and North America. Technol. Forecast. Soc. Chang. 2012, 79, 1111-1120. [CrossRef]

17. Hämäläinen, S.; Näyhä, A.; Pesonen, H.L. Forest biorefineries-A business opportunity for the Finnish forest cluster. J. Clean. Prod. 2011, 19, 1884-1891. [CrossRef]

18. Egea, F.J.; López-Rodríguez, M.D.; Oña-Burgos, P.; Castro, A.J.; Glass, C.R. Bioeconomy as a transforming driver of intensive greenhouse horticulture in SE Spain. New Biotechnol. 2021, 61, 50-56. [CrossRef] [PubMed] 
19. Jander, W.; Wydra, S.; Wackerbauer, J.; Grundmann, P.; Piotrowski, S. Monitoring bioeconomy transitions with economicenvironmental and innovation indicators: Addressing data gaps in the short term. Sustainability 2020, 12, 4683. [CrossRef]

20. Kardung, M.; Cingiz, K.; Costenoble, O.; Delahaye, R.; Heijman, W.; Lovrić, M.; van Leeuwen, M.; M’barek, R.; van Meijl, H.; Piotrowski, S.; et al. Development of the circular bioeconomy: Drivers and indicators. Sustainability 2021, 13, 413. [CrossRef]

21. Golden, J.R. Economics and national strategy: Convergence, global networks, and cooperative competition. Wash. Q. 1993, 16, 88-113. [CrossRef]

22. Goven, J.; Pavone, V. The Bioeconomy as Political Project: A Polanyian Analysis. Sci. Technol. Hum. Values 2015, 40, 302-337. [CrossRef]

23. BMBF. National Bioeconomy Strategy. Available online: https://www.bmbf.de/SharedDocs/Publikationen/de/bmbf/pdf/ national-bioeconomy-strategy.pdf;jsessionid=C1EDB1D4455DABF9146B0B1B861BBB79.live091?_blob=publicationFile\&v=2 (accessed on 1 March 2021).

24. Wohlgemuth, R.; Twardowski, T.; Aguilar, A. Bioeconomy moving forward step by step-A global journey. New Biotechnol. 2021, 61, 22-28. [CrossRef]

25. De Besi, M.; McCormick, K. Towards a bioeconomy in Europe: National, regional and industrial strategies. Sustainability 2015, 7 , 10461-10478. [CrossRef]

26. European Commission. Deploying the Bioeconomy in the EU: A Framework Approach for Bioeconomy Strategy Development; EC: Brussels, Belgium, 2021; Available online: https:/ /op.europa.eu/en/publication-detail/-/publication/2cf89630-e2bc-11eb-895a01aa75ed71a1/ (accessed on 4 August 2021).

27. Ayrapetyan, D.; Hermans, F. Introducing a multiscalar framework for biocluster research: A meta-analysis. Sustainability 2020, 12, 3890. [CrossRef]

28. Davide, C.V.C.; Chiesa, V.; Chiaroni, D. Industrial Clusters in Biotechnology: Driving Forces, Development Processes, and Management Practices; Imperial College Press: London, UK, 2005; pp. 1-3.

29. Zechendorf, B.; Aguilar, A. Regional biotechnology-The EU biocluster study. J. Commer. Biotechnol. 2011, 17, 209-217. [CrossRef]

30. Hermans, F. The potential contribution of transition theory of the analysis of bioclusters and their role in transition to bioeconomy. Biofuels Bioprod. Biorefin. 2017, 12, 265-276. [CrossRef]

31. Khalique, M.; Bin Shaari, J.A.N.; Isa, A.H.B.M. The road to the development of intellectual capital theory. Int. J. Learn. Intellect. Cap. 2013, 10, 122-136. [CrossRef]

32. Kozak, M. Strategic approach to intellectual capital development in regions. Int. J. Learn. Intellect. Cap. 2011, 8, 76-93. [CrossRef]

33. The Global Sustainable Competitiveness Index 2021. Available online: https://solability.com/the-global-sustainablecompetitiveness-index/the-index (accessed on 1 May 2021).

34. Boljanovic, J.D.; Dobrijević, G.; Cerovic, S.; Alcakovic, S.; Djokovic, F. Knowledge-based bioeconomy: The use of intellectual capital in food industry of Serbia. Amfiteatru Econ. 2018, 20, 717-731. [CrossRef]

35. Gârdan, D.A.; Andronie, M.; Gârdan, I.P.; Andronie, I.E.; Iatagan, M.; Hurloiu, I. Bioeconomy development and using of intellectual capital for the creation of competitive advantages by Smes in the field of biotechnology. Amfiteatru Econ. 2018, 20, 647-666. [CrossRef]

36. Zilberman, D.; Gordon, B.; Hochman, G.; Wesseler, J. Economics of sustainable development and the bioeconomy Appl. Econ. Perspect. Policy 2018, 40, 22-37. [CrossRef]

37. Urmetzer, S.; Pyka, A. Varieties of knowledge-based bioeconomies. In Knowledge-Driven Developments in the Bioeconomy; Dabbert, S., Lewandowski, I., Weiss, J., Pyka, A., Eds.; Springer: Cham, Switzerland, 2017; pp. 57-82.

38. Anghel, I.; Siminică, M.; Cristea, M.; Noja, G.G.; Sichigea, M. Bioeconomy credentials and intellectual capital: A comparative modelling approach for the E.U.-13 and E.U.-15. Econ. Res. Ekon. Istraz. 2019, 32, 2699-2722. [CrossRef]

39. Woźniak, E.; Tyczewska, A.; Twardowski, T. Bioeconomy development factors in the European Union and Poland. New Biotechnol. 2021, 60, 2-8. [CrossRef]

40. European Commision. Bridging the "Skills Gap" for a Bioeconomy in Europe. Available online: https://ec.europa.eu/research/ bioeconomy/conferences/bridging_the_skills_gap/index_en.htm (accessed on 10 April 2021).

41. Buttel, F.H. Ecological modernization as social theory. Geoforum 2000, 31, 57-65. [CrossRef]

42. Leoussis, J.; Brzezicka, P. Access-to-Finance Conditions for Investments in Bio-Based Industries and the Blue Economy; European Investment Bank: Luxembourg, 2017.

43. Scarlat, N.; Dallemand, J.F.; Monforti-Ferrario, F.; Nita, V. The role of biomass and bioenergy in a future bioeconomy: Policies and facts. Environ. Dev. 2015, 15, 3-34. [CrossRef]

44. BERST. Criteria and Indicators Describing the Regional Bioeconomy. Available online: https://www.wecr.wur.nl/ BerstPublications/D1.1\%20Criteria\%20and\%20Indicators\%20describing\%20Regional\%20Bioeconomy\%20(Oct\%202014).pdf (accessed on 30 April 2021).

45. Lewandowski, I. Securing a sustainable biomass supply in a growing bioeconomy. Glob. Food Sec. 2015, 6, 34-42. [CrossRef]

46. Renewable Energy Directive-RED II. Available online: http:/ / data.europa.eu/eli/dir/2018/2001/oj (accessed on 1 April 2021)

47. Giurca, A.; Späth, P. A forest-based bioeconomy for Germany? Strengths, weaknesses and policy options for lignocellulosic biorefineries. J. Clean. Prod. 2017, 153, 51-62. [CrossRef]

48. Lauka, D.; Slisane, D.; Ievina, L.; Muizniece, I.; Blumberga, D. When Bioeconomy Development Becomes a Biomass Energy Competitor. Environ. Clim. Technol. 2019, 23, 347-359. [CrossRef] 
49. Camia, A.; Rober, N.; Jonsson, R.; Pilli, R.; Garcia-Condado, S.; Lopez-Lozano, R.; van der Velde, M.; Ronzon, T.; Gurria, P.; M'Barek, R.; et al. Biomass Production, Supply, Uses and Flows in the European Union. First Results from an Integrated Assessment; Publications Office of the European Union: Luxembourg, 2018.

50. European Commission. Strategies and Other Policy Initiatives Dedicated to the Bioeconomy in the EU and Some Other Countries. Available online: http:/ / data.europa.eu/89h/990dcbce-11c8-44f4-a6f4-af7339c9b4ae (accessed on 1 January 2021).

51. Eurostat. Population by Educational Attainment Level, Sex and Age (\%)—Main Indicators. Available online: https://appsso. eurostat.ec.europa.eu/nui/submitViewTableAction.do (accessed on 1 April 2021).

52. Eurostat. GERD by Sector of Performance and Type of R\&D. Available online: https://ec.europa.eu/eurostat/databrowser/ view/RD_E_GERDACT_custom_1542958/default/table?lang=en (accessed on 1 April 2021).

53. European Commission. Biomass Production in the EU by Biomass Type. Available online: https://knowledge4policy.ec.europa. eu/bioeconomy/topic/biomass_en (accessed on 1 March 2021).

54. Ronzon, T.; M’Barek, R. Socioeconomic indicators to monitor the EU's bioeconomy in transition. Sustainability 2018, $10,1745$. [CrossRef]

55. European Commission. JRC—Bioeconomics-Query. Available online: https://datam.jrc.ec.europa.eu/datam/public/pages/ previousFilters.xhtml? dataset=7d7d5481-2d02-4b36-8e79-697b04fa4278 (accessed on 1 January 2021).

56. Food and Agriculture Organization of the United Nations (FAO). Land Use. Available online: https://www.fao.org/faostat/en/ \#data/RL (accessed on 1 March 2021).

57. D'Adamo, I.; Falcone, P.M.; Morone, P. A New Socio-economic Indicator to Measure the Performance of Bioeconomy Sectors in Europe. Ecol. Econ. 2020, 176, 106724. [CrossRef]

58. Woodside, A.G. Moving beyond multiple regression analysis to algorithms: Calling for adoption of a paradigm shift from symmetric to asymmetric thinking in data analysis and crafting theory. J. Bus. Res. 2013, 66, 463-472. [CrossRef]

59. Di Lucia, L.; Kronsell, A. The willing, the unwilling and the unable-explaining implementation of the EU Biofuels Directive. J. Eur. Public Policy 2010, 17, 545-563. [CrossRef]

60. Huang, C.W.; Huarng, K.H. Evaluating the performance of biotechnology companies by causal recipes. J. Bus. Res. 2015, 68, 851-856. [CrossRef]

61. Ragin, C.C. Fuzzy-Set Social Science; University of Chicago Press: Chicago, IL, USA, 2000; pp. 179-182.

62. Rihoux, B.; Ragin, C.C. Configurational Comparative Methods: Qualitative Comparative Analysis (QCA) and Related Techniques; Sage Publications: Thousand Oaks, CA, USA, 2008.

63. Pappas, I.O.; Woodside, A.G. Fuzzy-set Qualitative Comparative Analysis (fsQCA): Guidelines for research practice in Information Systems and marketing. Int. J. Inf. Manag. 2021, 58, 102310. [CrossRef]

64. Ragin, C.C. User's Guide to Fuzzy-Set/Qualitative Comparative Analysis. Manual Based on fsQCA 3.0; Department of Sociology, University of California: Irvine, CA, USA, 2017; p. 62.

65. Ragin, C.C. Redesigning Social Inquiry: Fuzzy Sets and Beyond; The University of Chicago Presss: Chicago, IL, USA, 2008.

66. Wagemann, C.; Schneider, C.Q. Qualitative comparative analysis (QCA) and fuzzy-sets: Agenda for a research approach and a data analysis technique. Comp. Sociol. 2010, 9, 376-396. [CrossRef]

67. Trueb, B. Integrating qualitative and quantitative data: Index creation using fuzzy-set QCA. Qual. Quant. 2013, 47, 3537-3558. [CrossRef]

68. Ragin, C.C.; Sean, D. Fuzzy-Set/Qualitative Comparative Analysis 3.0; Department of Sociology, University of California: Irvine, CA, USA, 2016.

69. Schneider, M.R.; Schulze-Bentrop, C.; Paunescu, M. Mapping the institutional capital of high-tech firms: A fuzzy-set analysis of capitalist variety and export performance. J. Int. Bus. Stud. 2010, 41, 246-266. [CrossRef]

70. Capatina, A.; Micu, A.; Micu, A.E.; Bouzaabia, R.; Bouzaabia, O. Country-based comparison of accommodation brands in social media: An fsQCA approach. J. Bus. Res. 2018, 89, 235-242. [CrossRef]

71. Greckhamer, T.; Misangyi, V.F.; Fiss, P.C. The Two QCAs: From a Small-N to a Large-N Set Theoretic Approach; Emerald Group Publishing Limited: Bingley, UK, 2013; Volume 38, ISBN 978-1-78190-778-8.

72. Ragin, C.C. Set relations in social research: Evaluating their consistency and coverage. Polit. Anal. 2006, 14, 291-310. [CrossRef]

73. Doloreux, D.; Parto, S. Regional innovation systems: Current discourse and unresolved issues. Technol. Soc. 2005, 27, 133-153. [CrossRef]

74. Robert, N.; Giuntoli, J.; Araujo, R.; Avraamides, M.; Balzi, E.; Barredo, J.I.; Baruth, B.; Becker, W.; Borzacchiello, M.T.; Bulgheroni, C.; et al. Development of a bioeconomy monitoring framework for the European Union: An integrative and collaborative approach. New Biotechnol. 2020, 59, 10-19. [CrossRef]

75. Pehlken, A.; Wulf, K.; Grecksch, K.; Klenke, T.; Tsydenova, N. More sustainable bioenergy by making use of regional alternative biomass? Sustainability 2020, 12, 7849. [CrossRef]

76. Tzelepi, V.; Zeneli, M.; Kourkoumpas, D.S.; Karampinis, E.; Gypakis, A.; Nikolopoulos, N.; Grammelis, P. Biomass availability in europe as an alternative fuel for full conversion of lignite power plants: A critical review. Energies 2020, 13, 3390. [CrossRef]

77. Hetemäki, L.; Hanewinkel, M.; Muys, B.; Ollikainen, M.; Palahí, M.; Trasobares, A. Leading the Way to a European Circular Bioeconomy Strategy; European Forest Institute: Joensuu, Finland, 2017; Volume 5.

78. Lühmann, M. Whose European bioeconomy? Relations of forces in the shaping of an updated EU bioeconomy strategy. Environ. Dev. 2020, 35, 100547. [CrossRef] 
79. Koukios, E.G. Knowledge-based greening as a new bioeconomy strategy for development: Agroecological utopia or revolution? In Law and Agroecology; Springer: Berlin/Heidelberg, Germany, 2015; pp. 439-450.

80. Canales, N.; Gladkykh, G.; Bessonova, E.; Fielding, M.; Johnson, F.X.; Peterson, K. Policy Dialogue on a Bioeconomy for Sustainable Development in the Baltic Sea; Stockholm Environment Institute: Stockholm, Sweden, 2020; Available online: https:/ / cdn.sei.org/ wp-content/uploads/2020/01/200129b-mash-fielding-workshop-bioeconomy-talinn-pr-1912h.pdf (accessed on 4 May 2021).

81. Khan, J.; Johansson, B.; Hildingsson, R. Strategies for greening the economy in three Nordic countries. Environ. Policy Gov. 2021, 1-13. [CrossRef]

82. Lange, L.; Hreggviðsson, G.Ó.; Björnsdóttir, B.; Brandt, A.; Hildén, K.; Jacobsen, B.; Jessen, A.; Karlsson, E.N.; Lindedam, J.; Mäkelä, M.; et al. Development of the Nordic Bioeconomy; Nordic Council of Ministers: Copenhagen, Denmark, 2015; Available online: https: / / library.oapen.org/bitstream/handle/20.500.12657/32774/605483.pdf?sequence=1 (accessed on 1 January 2021).

83. Wilde, K.; Hermans, F. Deconstructing the attractiveness of biocluster imaginaries. J. Environ. Policy Plan. 2021, 23, 227-242. [CrossRef]

84. Duque-Acevedo, M.; Belmonte-Ureña, L.J.; Plaza-Úbeda, J.A.; Camacho-Ferre, F. The management of agricultural waste biomass in the framework of circular economy and bioeconomy: An opportunity for greenhouse agriculture in Southeast Spain. Agronomy 2020, 10, 489. [CrossRef]

85. Piotrowski, S.; Carus, M.; Essel, R. Global Bioeconomy in the Conflict between Biomass Supply and Demand. Ind. Biotechnol. 2015, 11, 308-315. [CrossRef]

86. Tiron-Tudor, A.; Nistor, C.S.; Ştefănescu, C.A. The role of universities in consolidating intellectual capital and generating new knowledge for a sustainable bio-economy. Amfiteatru Econ. 2018, 20, 599-615. [CrossRef]

87. Vătămănescu, E.M.; Alexandru, V.A.; Cristea, G.; Radu, L.; Chirica, O. A demand-side perspective of bioeconomy: The influence of online intellectual capital on consumption. Amfiteatru Econ. 2018, 20, 553-566. [CrossRef]

88. Nedelea, A.; Mironiuc, M.; Huian, M.C.; Bîrsan, M.; Bedrule-Grigoruta, M.V. Modeled Interdependencies between Intellectual Capital, Circular Economy and Economic Growth in the Context of Bioeconomy. Amfiteatru Econ. 2018, 20, 616. [CrossRef] 